Pembelajaran Tari Indang Menggunakan Model Pembelajaran Tutor Sebaya Kepada Siswa Kelas VII Sekolah Menengah Pertama SMP 14 Palembang Irnawilis

Pengaruh Metode Pembelajaran Kooperatif Terhadap Hasil Belajar Menyanyikan Lagu Wajib Nasional Bagimu Negeri Kepada Siswa Kelas VII SMP Negeri 35 Palembang Kusniarti

Pembelajaran Membuat Ragam Hias Menggunakan Media Bambu Dengan Metode

Pembelajaran Lagu Daerah Sik Sik Sibatumahikam Dengan Media Instrument Kolintang Untuk PIKPP (Persatuan Ibu-lbu Karyawan PT Pusri Palembang) Sumatera Selatan Rio eka putra

Seni Tari Antara Ruang Dan Waktu

Rully rochayati

Bentuk dan Struktur Musik Pertunjukan Rejung

Silo siswanto

Menjadi Seniman Jawa

Treny hera

Tantangan Budaya Nusantara Dalam Kehidupan Masyarakat Di Era Globalisasi Naomi diah budi setyaningrum

Struktur Penyajian Sastra Tutur Guritan Pada Masyarakat Trans Muara Dua 


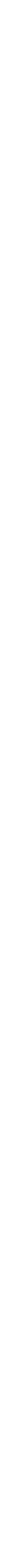




\section{DAFTAR ISI}

Tari Gajah Munggang dalam Perspektif Sosio-Kultural Masyarakat Suku Sawang Belitung

Efita Elvandari

Pembelajaran Tari Indang Menggunakan Model Pembelajaran Tutor Sebaya Kepada Siswa

Kelas VII Sekolah Menengah Pertama SMP 14 Palembang

Irnawilis

Pengaruh Metode Pembelajaran Kooperatif Terhadap Hasil Belajar Menyanyikan Lagu Wajib

Nasional Bagimu Negeri Kepada Siswa Kelas VII SMP Negeri 35 Palembang

Kusniarti

Pembelajaran Membuat Ragam Hias Menggunakan Media Bambu Dengan Metode

Demonstrasi Pada Siswa Kelas VII SMP Negeri 1 Talang Kelapa

Lili purnama sari dan mainur

Pembelajaran Lagu Daerah Sik Sik Sibatumahikam Dengan Media Instrument Kolintang

Untuk PIKPP (Persatuan Ibu-lbu Karyawan PT Pusri Palembang) Sumatera Selatan

Rio eka putra

Seni Tari Antara Ruang Dan Waktu

Rully rochayati

Bentuk dan Struktur Musik Pertunjukan Rejung

Silo siswanto

Menjadi Seniman Jawa

Treny hera

Tantangan Budaya Nusantara Dalam Kehidupan Masyarakat Di Era Globalisasi

Naomi diah budi setyaningrum

Struktur Penyajian Sastra Tutur Guritan Pada Masyarakat Trans Muara Dua Kecamatan Gumay

Ulu Kabupaten Lahat

Nofroza Yelli dan Juliana Tata Parista 


\title{
BENTUK DAN STRUKTUR MUSIK \\ PERTUNJUKAN REJUNG
}

Oleh:

Silo Siswanto

(Dosen FKIP Program Studi Pendidikan Sendratasik Universitas PGRI Palembang)

\begin{abstract}
ABSTRAK
Rejung merupakan seni pertunjukan rakyat -musik-, di mana teksnya berbentuk pantun yang disenandungkan bersama dengan permainan gitar, piol - berbentuk seperti biola - dan dambus. Munculnya rejung bermula dari kesenian ta'dut dan sardudun. Penelitian ini bertujuan: Menjelaskan bentuk dan struktur musik pertunjukan rejung.

Bentuk dan struktur musik pada pertunjukan rejung memiliki ke khasan tersendiri bagi masyarakat Sumatera Selatan. Empat poin yang harus diperhatikan dalam melihat bentuk dan struktur rejung yakni (1) deskripsi pertunjukan rejung, (2) bentuk musik pertunjukan rejung, (3) pantun dan kalimat musik sebagai struktur pembentuk rejung, dan (4) konsep gotong royong pada pertunjukan rejung.

Hasil penelitian yang diperoleh (1) pemahaman bentuk dari penyajian pertunjukan rejung dan pemahaman struktur musik rejung secara musikal.
\end{abstract}

Kata Kunci: Bentuk, Struktur Musik, Pertunjukan Rejung

\section{A. PENDAHULUAN}

Propinsi Sumatera Selatan memiliki kesenian berupa kesenian rejung. Rejung merupakan seni pertunjukan rakya -musik-, di mana teksnya berbentuk pantun yang disenandungkan bersama dengan permainan gitar, piol -berbentuk seperti biola- dan dambus. Penggunaan istilah rejung selaras dengan pengertiannya yakni bearti pantun yang disenandungkan (Kordin, wawancara, 06 Februari 2014).

Bentuk sajian pertunjukan rejung ada dua macam. Pertama, berbentuk gitar tunggal, yakni permainan rejung dibawakan oleh satu orang, pemain gitarnya biasanya sekaligus berperan sebagai penembang atau penyanyi dan ada juga yang bukan dari pemain gitar. Kedua, rejung dimainkan secara bersama atau disebut dengan istilah setebak. Umumnya, di dalam sajian pertunjukan rejung, pantun yang dilantunkan diulang dua sampai tiga kali setiap barisnya. Kemudian dipertegas oleh Hanafiah dan tim berpendapat bahwa; "Musik di Sumatera Selatan ada yang ditampilkan secara tunggal dengan memainkan 1 (satu) alat musik atau bersifat 
individual dan ada yang ditampilakan secara berkelompok yaitu gabungan beberapa alat musik ataun ensamble" (Hanafiah dan tim, 2006:39)

Penyajian pertunjukan rejung dalam pelantunan teks pantunnya yang sajkan secara berulang-ulang atau repetisi. Hal ini tidak dapat dipungkiri bahwa pengulangan tersebut akan membentuk struktur musik rejung itu sendiri. Sebagaimana menurut Dharsono bahwa Repetisi merupakan pengulangan unsur-unsur pendukung karya seni -rejung-. Repetisi atau ulang merupakan selisih antara dua wujud yang terletak pada ruang dan waktu, maka sifat paduannya bersifat satu matra yang dapat diukur dengan interval atau jarak ruang, serupa dengan interval waktu antara dua nada musik beruntun yang sama.

Berdasarkan paparan di atas menegaskan bahwa 'bentuk dan struktur musik pada pertunjukan rejung' merupakan perspektif dalam penelitian ini. Problematika penelitian adalah bagian pokok dari suatu kegiatan penelitian disebut perumusan masalah, yang berupa pertanyaan yang akan dicari jawabannya (Arikunto, 1998:52).

\section{Rumusan Masalah}

Problematika penelitian adalah bagian pokok dari suatu kegiatan penelitian disebut perumusan masalah, yang berupa pertanyaan yang akan dicari jawabannya (Arikunto, 1998:52). Berpijak pada pemaparan di atas maka, penelitian ini mengajukan persoalan yang dirumuskan dalam bentuk pertanyaan-pertanyaan berikut ini:

"Bagaimanakah bentuk dan struktur musik pada pertunjukan rejung di kecamatan Pulau Beringin ?".

\section{Tujuan Penelitian}

- Menjelaskan bentuk dan struktur musik pertunjukan rejung.

- Untuk menumbuh-kembangkan rejung di tengah masyarakat Sumatera Selatan pada umumnya.

\section{Landasan Teoritis}

Pengertian kata Bentuk berdasarkan Kamus Besar Bahasa Indonesia yakni berarti wujud. Wujud dalam kesenian ada yang tampak dan dapat kita lihat seperti tari, lukis dan patung. Ada wujud yang tidak terlihat, akan tetapi bisa didengarkan, bisa diteliti dan dibahas struktur penyusunannya, seperti musik maupun nyanyian.

Pertunjukan rejung dalam melihat bentuk dan struktur penyajiannya, peneliti akan membagi subbabnya yakni sekurang-kurangnya ada empat poin yang harus diperhatikan yakni; deskripsi pertunjukan rejung, bentuk musik dalam pertunjukan rejung, pantun dan kalimat musik sebagai struktur pembentuk rejung dan Konsep gotong royong pada pertunjukan rejung. Apabila keempat poin tersebut dapat dijelaskan secara cermat, maka bentuk penyajian rejung di Kecamatan Pulau Beringin akan dapat dijelaskan secara rinci oleh 
peneliti. Keempat subbab yang dipaparkan di atas akan menjelaskan bentuk penyajian rejung dan sekaligus menjelaskan struktur musik rejung.

Sebagai reperensi tambahan dan sekaligus untuk memperkuat analisis pada penelitian ini, tentang struktur musik rejung, peneliti menggunakan teori ilmu bentuk analisis musik dalam tulisan Jones buku yang berjudul Music Theory yakni

It is apparent that the names given to small forms and segment of music are samewhat analogous to the terms used for sentence contruction. Motive, phrase member, phrase, period, double period and phrase period. (Jones,1974:102)

Jones menjelaskan penyusun pada bagian-bagian kalimat musik, dapat dianalogikan atau disamaartikan sebagaimana kita menyusun kalimat dalam bahasa. Adapun istilah-istilah dalam menyusun kalimat melodi dalam karya musik. Motif (figure): ide melodi yang terkecil, terdiri dari beberapa nada dan ritme irama-, bagian Phrase : Bagian dari phrase yang dikembangkan dari motif, phrase : Suatu ide musik yang sudah lengkap (tetapi belum selesai), yang diakhiri dengan sebuah kadens -nutup-, Periode : Gabungan dua buah phrase, yang diakhiri dengan kadens yang kuat, dianalogkan dengan sebuah kalimat bahasa Gabungan tiga atau lebih phrase.

Berbagai pendekatan yang dilakukan hal ini merupakan sebagai landasan konseptual peneliti dalam membahas bentuk dan struktur musik pada pertunjukan rejung di kecamatan Pulau Beringin Sumatera Selatan.

\section{B. METODE PENELITIAN}

Metode dalam penelitian ini peneliti melakukan penyusunan metode penelitian secara sistematis. Di antaranya tersusun dalam bentuk struktur berikut ini 1. (Studi Pustaka) yakni proses kerja ini dilakukan dengan jalan jelajah buku, jurnal dan lain-lain yang terkait langsung terhadap objek kajian. Studi ini dilakukan terhadap berbagai sumber literatur yang masih memiliki hubungan dengan data atau informasi yang menjadi fokus kajian yang sedang diteliti, 2. (Observasi) Observasi adalah teknik pengumpulan data yang dilakukan hampir bersamaan dengan wawancara, waktunya yakni bertepatan dengan masyarakat melakukan pertemuan. Pertemuan tersebut oleh adat suku Semende sudah menjadi tradisi dan seringkali rejung ditampilkan sebelum acara dimulai, 3. (Wawancara) Wawancara adalah metode penggalian data secara langsung di lapangan. Peneliti menggunakan teknik wawancara tidak formal. Pertimbangan yang digunakan adalah suasananya keakraban dan kekeluargaan yang telah terbangun sebelumnya. Teknik ini memberikan peluang berkembangnya pertanyaan yang diajukan kepada narasumber sehingga informasi yang diberikan oleh narasumber dapat lebih komprehensif. 


\section{Landasan Teoritis}

Pengertian kata Bentuk berdasarkan Kamus Besar Bahasa Indonesia yakni berarti wujud. Wujud dalam kesenian ada yang tampak dan dapat kita lihat seperti tari, lukis dan patung. Ada wujud yang tidak terlihat, akan tetapi bisa didengarkan, bisa diteliti dan dibahas struktur penyusunannya, seperti musik maupun nyanyian.

Pertunjukan rejung dalam melihat bentuk dan struktur penyajiannya, peneliti akan membagi subbabnya yakni sekurang-kurangnya ada empat poin yang harus diperhatikan yakni; deskripsi pertunjukan rejung, bentuk musik dalam pertunjukan rejung, pantun dan kalimat musik sebagai struktur pembentuk rejung dan Konsep gotong royong pada pertunjukan rejung. Apabila keempat poin tersebut dapat dijelaskan secara cermat, maka bentuk penyajian rejung di Kecamatan Pulau Beringin akan dapat dijelaskan secara rinci oleh peneliti. Keempat subbab yang dipaparkan di atas akan menjelaskan bentuk penyajian rejung dan sekaligus menjelaskan struktur musik rejung. Sebagai reperensi tambahan dan sekaligus untuk memperkuat analisis pada penelitian ini, tentang struktur musik rejung, peneliti menggunakan teori ilmu bentuk analisis musik dalam tulisan Jones buku yang berjudul Music Theory yakni

It is apparent that the names given to small forms and segment of music are samewhat analogous to the terms used for sentence contruction. Motive, phrase member, phrase, period, double period and phrase period. (Jones,1974:102) Jones menjelaskan penyusun pada bagian-bagian kalimat musik, dapat dianalogikan atau disamaartikan sebagaimana kita menyusun kalimat dalam bahasa. Adapun istilahistilah dalam menyusun kalimat melodi dalam karya musik. Motif (figure): ide melodi yang terkecil, terdiri dari beberapa nada dan ritme -irama-, bagian Phrase : Bagian dari phrase yang dikembangkan dari motif, phrase : Suatu ide musik yang sudah lengkap (tetapi belum selesai), yang diakhiri dengan sebuah kadens -nutup-, Periode : Gabungan dua buah phrase, yang diakhiri dengan kadens yang kuat, dianalogkan dengan sebuah kalimat bahasa Gabungan tiga atau lebih phrase.

Berbagai pendekatan yang dilakukan hal ini merupakan sebagai landasan konseptual peneliti dalam membahas bentuk dan struktur musik pada pertunjukan rejung di kecamatan Pulau Beringin Sumatera Selatan.

\section{PEMBAHASAN}

\section{A. Deskripsi Pertunjukan Rejung}

Pertunjukan rejung jika dipaparkan berdasarkan materi sajian maka pembahasannya bermula dari seorang pemain piol yang memainkan permainan melodi awal. Permainan piol ini berfungsi pula untuk menuntun vokal dalam memulai menembangkan pantun-pantun yang dilagukan. Pantun tesebut dimainkan kurang lebih terdiri dari empat pantun atau lebih kemudian diringi oleh pemain musik yang lain, setelah personil vokal rejung menembangkan pantunnya, maka pantun tersebut di ulangi lagi untuk ditembangkan oleh personil yang lainnya satu persatu dengan cara bergiliran. Adapun secara lebih rinci, deskripsi pertunjukan rejung dipaparkan dalam sub bab berikut ini. 


\section{Pemain}

Pemain rejung secara umum berjumlah lima orang. Masing-masing pemain memainkan alat musik berdasarkan pada fungsi permainannya masing-masing. Pemain piol, berfungsi melantunkan melodi di awal sajian serta membantu menentukan tingkat suara untuk vokal. Gambus membuat ritmis serta melodis, dua pemain gitar memainkan melodi yang bersamaan sehingga menimbulkan suara petikan melodi gitar yang cukup tebal. Praktiknya, dua orang sama-sama memainkan gitar, satu orang sebagai pemain piol, satu orang memainkan gambus dan satu orang lagi sebagai vokal. Meskipun sudah ada satu orang yang membidangi vokal, namun dalam praktiknya pemain lainnya juga harus bernyanyi.

Seluruh pemain rata-rata berusia senja, dan umumnya terdapat tokoh agama atau adat sebagai pelantun atau pemain musik. Keahlian bermain rejung yang diperoleh para pemain didapatkan dari pengalaman secara langsung yang diterima dari pendahulunya. Tidak ada sistem pembelajaran secara formal. Keahlian semacam ini diperoleh dari seringnya para pemain rejung memainkan rejung.

\section{Arena dan waktu Pertunjukan}

Arena pentas yang digunakan dalam pertunjukan rejung terbagi menjadi tiga tempat. Masing-masing tempat dapat digunakan sesuai dengan situasi yang dihadapi. Adapun ketiga tempat arena pentas tersebut adalah: (1) panggung terbuka; (2) halaman rumah; (3) di dalam rumah. Mengenai lokasi pertunjukan di atas panggung, ketinggian panggung tidak lebih dari satu meter. Panggung biasanya telah disediakan oleh panitia penyelenggara kegiatan. Pertunjukan ketika di halaman rumah, adakalanya tanpa diberikan panggung. Dalam pertunjukan di halaman rumah biasanya disediakan kursi untuk pemain rejung dan penonton. Kursi disusun secara melingkar. Artinya, posisi penonton berbentuk melingkar dan memutari pemain rejung yang posisinya ada di tengah-tengah. Ketika pertunjukan dilakukan di dalam rumah, seluruh pemain tampil dengan duduk bersila dan penonton pun masih sama pada posisi melingkari pemain rejung.

Mengingat tempat pertunjukannya dilakukan di tempat yang tidak ditentukan batasannya secara tegas, maka penonton dapat melihat pertunjukan rejung dari segala penjuru arah, bahkan penonton dan pemain rejung ini tidak memiliki jarak yang sangat tegas. Sehingga memungkinkan pemain rejung dapat melakukan interaksi dengan para penonton atau sebaliknya. Interaksi tersebut misalnya penonton berkomentar dengan sangat lantang 'hajar mang'1 dan komentar ini menurut pemain tidak mengganggu, karena pemain berpendapat bahwa terdapat pesan-pesan yang diinginkan oleh penontonnya. Hal ini memperlihatkan bahwa pertunjukan seni rakyat memiliki karakter dan ciri khusus, ciri-ciri tersebut terletak pada interaksi yang terjalin di antara penonton dan pemain yang tidak ada aturan yang ketat. Pada posisi ini rejung memperlihatkan sebagai seni publik. Menurut Mudji Sutrisno pertunjukan dengan ciri publik adalah pertunjukan yang dapat dinikmati oleh kalangan masyarakat luas dan memiliki ciri khas langsung yakni langsung dipagelarkan (2005: 92).

${ }^{1}$ Ungkapan ini dilontarkan secara sepontan oleh penonton sebagai wujud kepuasan dirinya atas pertunjukan rejung yang menyentuh perasaan. Mang dalam bahasa Melayu adalah panggilan bagi orang lakilaki dewasa di Sumatera Selatan. 
Rejung biasanya tampil dalam dua tema acara yang berbeda. Tema pertama menyangkut dengan kegiatan keagamaan, kedua menyangkut dengan kegiatan kemasyarakatan atau adat istiadat. Pentas dalam tema keagamaan di antaranya perayaan Hari Raya Idul Fitri, Hari Raya Idul Adha, Maulid Nabi dan Khotam al Qur'an. Sedangkan pertunjukan dalam rangka kegiatan sosial kemasyarakatan atau adat istiadat di antaranya adalah perkawinan, khitanan, musyawarah adat, perkumpulan muda-mudi buat kembang di dalam acara perkawinan sebelum akad nikah dilaksanakan, serta pertunjukan dalam memperingati hari-hari besar nasional, misalnya agustus-an.

\section{Penggunaan Alat Musik}

Alat musik yang digunakan dalam rejung meliputi piol, gitar, dan dambus. Seluruh alat musik berjenis chordophone, yakni alat musik yang sumber bunyinya dihasilkan dari senar yang dibentangkan dan dimainkan dengan cara dipetik dan digesek. Seluruh alat musik yang digunakan untuk rejung adalah buatan sendiri seniman rejung. Gitar yang digunakan meskipun ada yang lebih bagus, namun pemain tidak menghendaki untuk mengganti gitarnya dengan gitar yang baru. Gitar lama buatan tangan mereka sendiri ini usianya hampir 50 tahun. Adapun secara visual alat musik dalam rejung dapat terlihat pada gambar berikut ini.

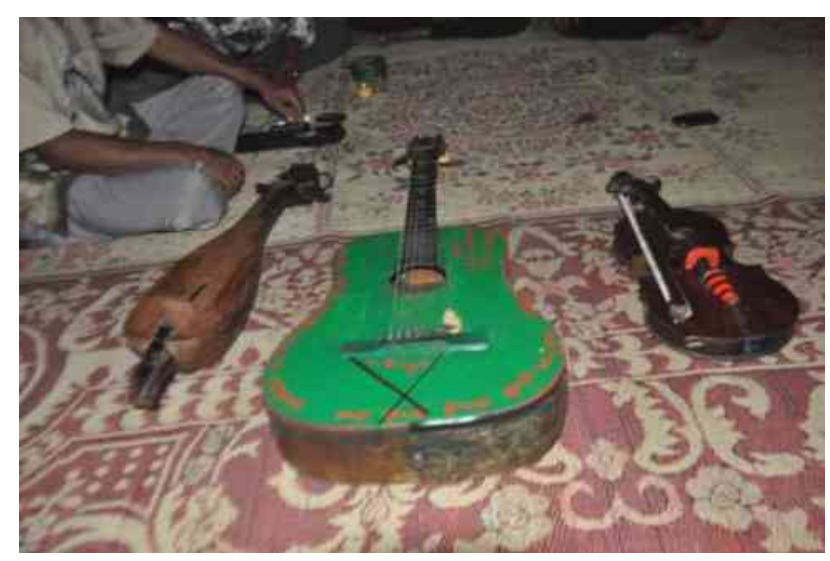

Gambar 1. Alat Musik Gambus, Gitar dan Piol dalam Rejung

\section{B. Bentuk Musik dalam Pertunjukan Rejung}

Bentuk musik secara umum dibingkai oleh kerangka musikal sebagaimana halnya kerangka bagi makhluk hidup sehingga sangat besar peranannya bagi suatu karya musik. Sedangkan mengenai 'bentuk' sendiri didefinisikan sebagai struktur, artikulasi, sebuah hasil kesatuan menyeluruh dari suatu hubungan berbagai faktor yang saling bergayutan atau lebih tepatnya suatu cara di mana keseluruhan aspek bisa dirakit (Langer, 1988: 16). Mengingat di dalam rejung alat musik yang digunakan bersifat melodis maka aspek bentuk rejung seluruhnya menyandarkan pada bangunan melodi yang dirajut oleh masing-masing instrumen dan persoalan istilah melodi dalam permainan rejung ini oleh masyarakat adat suku Semende dinamakan dengan istilah ayunan. 
Rejung di dalam konteks musikal secara eksplisit pun menuntut keterlibatan menyeluruh bagi seluruh pemainnya. Musiknya pun harus mengindahkan detail-detail. Melihat proses tersebut sangat memungkinkan memberikan pengaruh terhadap kepekaan, keteraturan dan kehalusan yang dirasakan oleh masyarakat penikmatnya. Perlu ditekankan di sini bahwa musik dalam konteks ini tidak memposisikan diri sebagai pengiring namun menjadi pokok dalam permainan rejung. Artinya, posisi musik memiliki otoritas untuk mengendalikan teks pantun yang dimainkan. Hal ini dapat terlihat ketika teks lagu - pantun - menyesuaikan dengan ayunan lagu, dan ini dapat terlihat dari pemenggalan kalimat teks lagu berjudul 'Adat Semende' dalam bentuk notasi berikut ini.

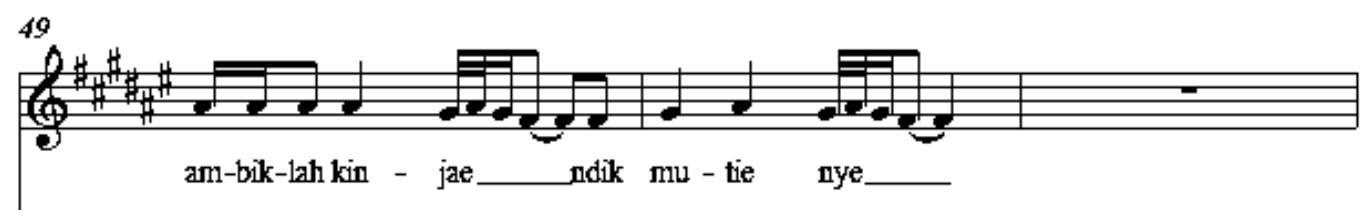

Notasi di atas memperlihatkan bagaimana teks lagu ambiklah, oleh penembang disajikan dengan mengikuti ayunan atau melodi lagu. Kenyataan ini memperlihatkan bahwa pantun secara empiris mengikuti sajian ayunan musik, dan dalam pembentukan alunan melodi lagu, teks sepenuhnya memiliki kemandirian untuk diolah sesuai dengan perasaan penembang. Otoritas penembang dalam menyajikan lagu dengan mendasarkan pada perasaannya pun secara kontekstual cukup relevan jika dihubungkan dengan sisi historis rejung, bahwa fenomena rejung awalnya berangkat dari tradisi seni sastra tutur, yakni ta'dut dan sardudun.

Kedua seni sastra tutur ini disajikan tanpa tambahan alat musik layaknya rejung. Aspek yang sama dari ta'dut maupun sardudun dengan rejung adalah sama-sama memiliki cara penuturan yang khas, yakni pada bagian akhir kalimat cara memverbalkannya awalnya datar dan selanjutnya menurun dengan frekuensi suara yang rendah. ${ }^{2}$ Pengetahuan awal mengenai seni sastra tutur tersebut menunjukkan bahwa sejak awal masyarakat adat suku Semende telah mengerti dan memahami teks lagu, karena sastra tutur menjadi tradisi turun temurun bagi masyarakat adat suku Semende.

Pada tahap ini cukup beralasan apabila pengetahuan awal penembang terhadap teks lagu sudah terbentuk sebelumnya. Pengalaman masyarakat adat suku Semende tatkala menghidupi tradisi sastra tutur tidak membuat pesan lantas tidak dapat diterima. Pada sisi lain justru peran musik dalam rejung menurut mereka justru membuat pesan menjadi lebih hidup, dan memiliki kesan mempesona hingga membuat masyarakat adat suku Semende berbondong-bondong untuk mendekat dan bersama-sama menikmati sajian pertunjukan rejung.

Fenomena ini menunjukkan bahwa pantun sebagai teks yang dilantunkan sepenuhnya mengikuti ayunan yang dibangun oleh alat musik. Secara kebahasaan, aspek syair dalam pantun sebagai material ayunan turut dibentuk oleh pengaruh dialek bahasa adat suku Semende. Dialek bahasa pada masyarakat adat Semende senantiasa menggunakan akhiran //è// pada akhir katanya, selain itu bunyi huruf //r// diverbalkan tidak secara tepat, namun diucapkan menjadi //kh//. ${ }^{3}$

\footnotetext{
${ }^{2}$ Suara frekuensi rendah dalam konteks ini mengarah pada suara bas. 3 Sebagai contoh kata 'berlari' diucapkannya menjadi belakhi.
} 
Pada sisi teknis penyajian, ketika penembang memulai sajian vokal. Dirinya harus menyesuaikan diri dengan pemainan ayunan piol. Ada kecenderungan bahwa vokal harus mengikuti ayunan piol. Hal ini menunjukkan bahwa awal terbentuknya ayunan vokal seluruhnya dikonstruksikan oleh ayunan awal yang dibangun oleh alat musik piol dan ini dalam rejung dikenal dengan istilah ngajak.

Ngajak ialah permainan ayunan yang digunakan sebagai tanda masuknya penembang dalam memainkan sajian vokal dalam berbagai bagian dalam permainan rejung dan ini berfungsi agar penembang tidak menyajikan nada-nada sumbang dalam permainan rejung. Maksud 'berbagai bagian' dalam konsep ngajak ini menyangkut dengan perpindahan dari frase kalimat lagu satu menuju ke frase kalimat lagu selanjutnya, dan diakhiri dengan istilah nutup. Nutup adalah istilah yang digunakan untuk menyebut akhir dari permainan pertunjukan rejung.

Implementasi mengenai konsep ngajak ini dapat terlihat pada lagu berjudul "Adat Semende" dan agar dapat terlihat di mana letak ngajak, maka peneliti menyertakan transkrip notasinya pada bahasan selanjutnya. Teks lagu berjudul "Adat Semende" digunakan sebagai contoh karena teks ini satu-satunya yang ditembangkan dalam rejung tanpa harus melakukan perubahan kalimat pantun. Hal ini disebabkan lirik pantun sudah berbentuk sebelumnya. Perlu dicatat, bahwa tidak semua pantun yang ada di masyarakat adat suku Semende dapat dimainkan dalam pertunjukan rejung, dan ini menyangkut dengan struktur rejung, yang meliputi pantun dan kalimat musik. Pantun terdiri dari sampiran dan isi, kemudian kalimat musik terdiri dari frase-frase. Sedangkan mengenai pembahasan struktur rejung agar dapat lebih jelas, maka hendak dipaparkan dalam sub-bab selanjutnya. Adapun konsep ngajak dan nutup dapat terlihat pada transkrip notasi di bawah ini.

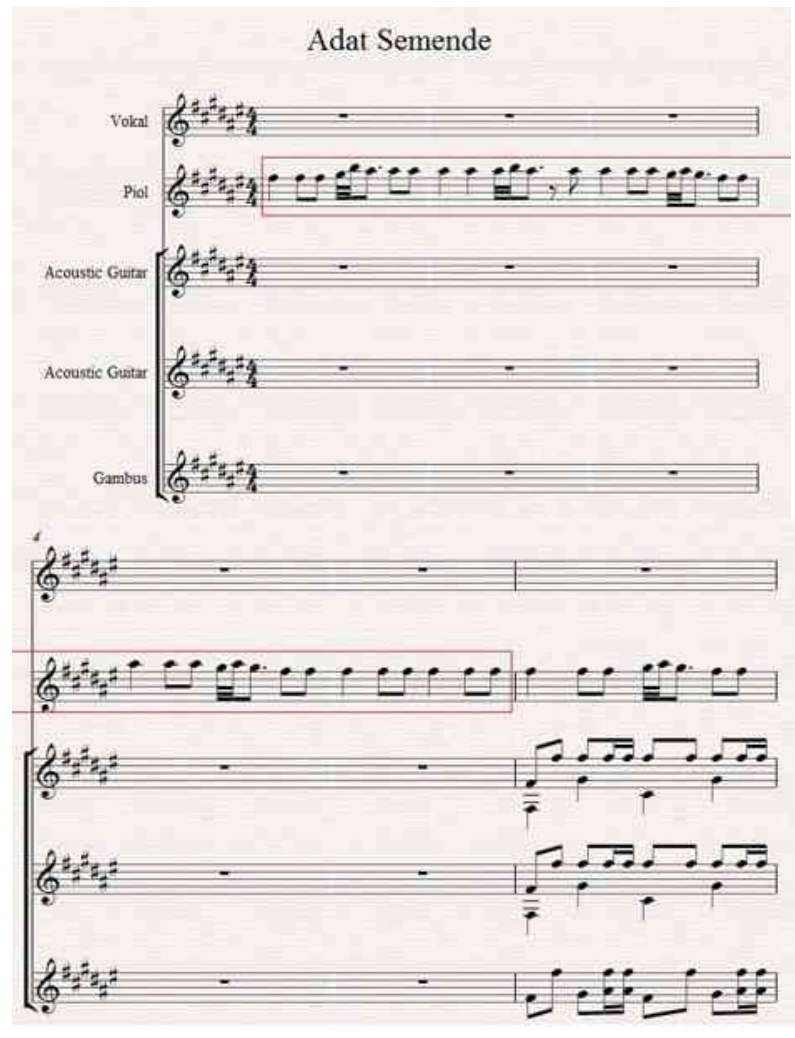


Notasi ngajak di atas yang diberikan garis merah adalah notasi yang disajikan oleh piol. Pada tahap awal ini piol mempunyai kebebasan memainkan ayunan atau melodi tanpa terikat oleh tempo. Adapun notasi nutup dapat terlihat pada notasi di bawah ini.
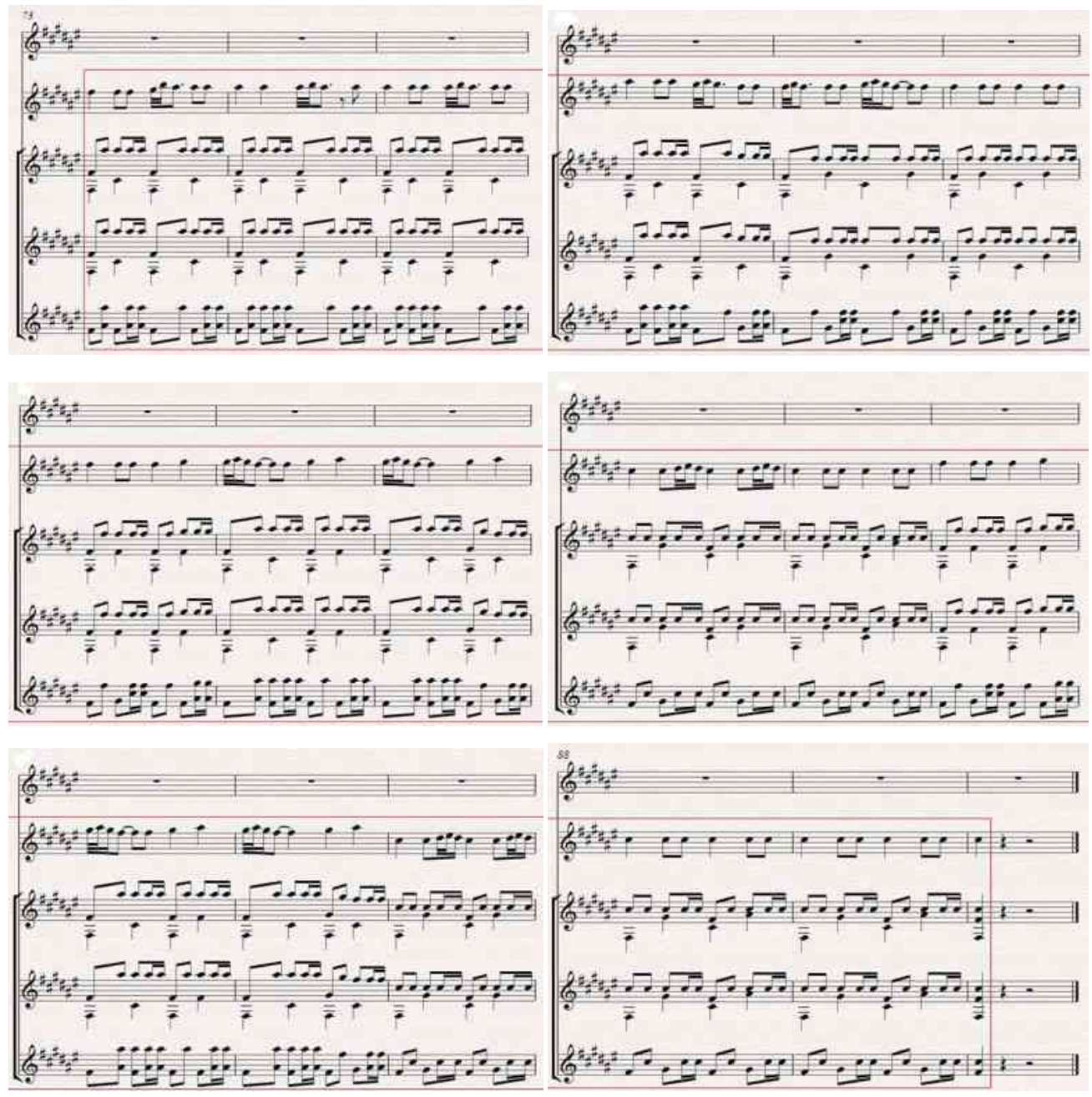

Notasi pada bagian nutup dalam rejung ini memiliki perbedaan dengan melodi ngajak. Letak perbedaanya yakni apabila melodi ngajak pada awalnya hanya dimaikan oleh piol dengan tidak terikat dengan tempo, pada tahap nutup, ayunan atau melodinya dimainkan secara bersama-sama dengan memperhatikan tempo.

\section{Pantun dan Kalimat Musik Sebagai Struktur Pembentuk Rejung}

Transkrip notasi di atas menunjukkan bagaimana pertunjukan rejung menyimpan berbagai istilah musik yang lahir dari tradisi musik mereka sendiri. Pemaparan mengenai penjelasan wujud musik pada pertunjukan rejung yang telah dijelaskan pada sub-bab sebelumnya dapat ditarik benang merah bahwa pantun dan musik dalam pertunjukan rejung terkemas menjadi satu kesatuan, dan ini dapat terlihat pada gambaran notasi di atas.

Adapun pada pembahasan sub bab ini peneliti perlu memperjelas terlebih dahulu pokok bahasan. Subbab ini peneliti mengambil judul "Pantun dan Kalimat Musik sebagai Struktur Pembentuk Rejung". Artinya, 
persoalan pantun dalam konteks ini perlu peneliti paparkan terlebih dahulu, yakni dengan mendasarkan pada temuan data di lapangan. Selanjutnya diteruskan memaparkan mengenai persoalan kalimat musik.

Kordin berpendapat, pantun yang digunakan dalam rejung seluruhnya berisi sampiran dan isi. Menurutnya, sampiran berfungsi sebagai pembentuk rima, dan hal ini digunakan sebagai pembayang untuk masuk ke dalam isi. Kordin menjelaskan pula bahwa isi adalah pesan yang hendak disampaikan, atau dapat dikatakan sebagai sesuatu yang pokok dalam pantun (wawancara, 20 Agustus 2014). Sebagai gambaran penjelas mengenai pantun yang direjungkan, berikut diberikan contoh pantun yang dimaksud.

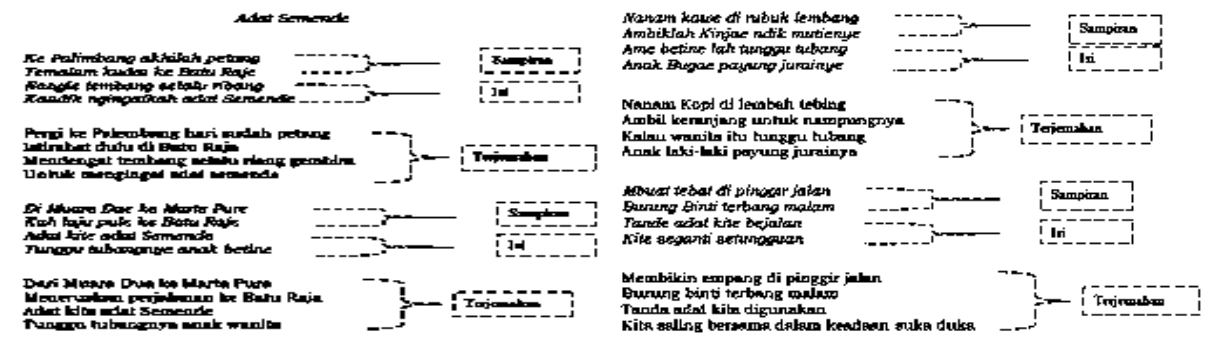

Pada pembahasan persoalan kalimat musik, peneliti perlu memberikan contoh sederhana terlebih dahulu, misalnya dalam konteks studi bahasa, kata-kata yang saling disambungkan dengan mempertimbangkan aturan pengkalimatan maka hal ini akan membentuk serangkaian kalimat yang bermakna dan berarti. Paparan contoh sederhana tersebut apabila dikontekstualisasikan pada musik dapat dijumpai satu kemiripan. Hal ini dijelaskan pula oleh Sumaryo. Menurutnya, melodi yang dilagukan juga merupakan kalimat musik. Kalimat musik ini dinamakan tema (1978: 33). Tema adalah ide musikal dan unsur struktural kecil dalam musik adalah frase (Miller, 2001: 85). Di dalam frase masih terdapat motif. Motif adalah kesatuan-kesatuan kecil yang sudah memberikan kesan adanya perasaan tertentu pada pendengarnya (Sumaryo, 1978: 110). Dengan demikian motif adalah aspek terkecil kalimat musik dalam pertunjukan rejung.

Paparan mengenai persoalan pantun dan kalimat musik di atas selanjutnya dapat memberikan gambaran mengenai bagaimana rejung terbentuk, atau bagaimana struktur rejung itu dapat terbangun. Apabila dikonstruksikan dalam bentuk bagan maka, struktur rejung dapat terlihat seperti bagan di bawah ini.

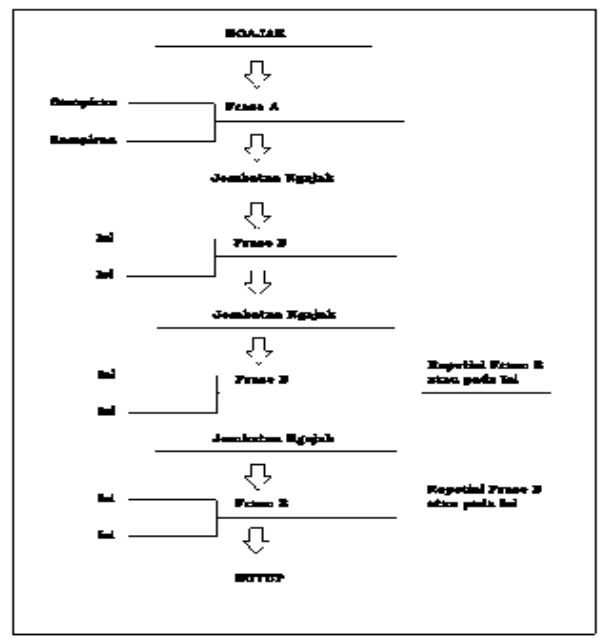

Gambar 2. Struktur Rejung 
Struktur pembentuk rejung yang diwujudkan pada bagan di atas apabila dihadirkan dalam bentuk notasi dapat terlihat seperti di bawah ini.

Notasi Ngajak
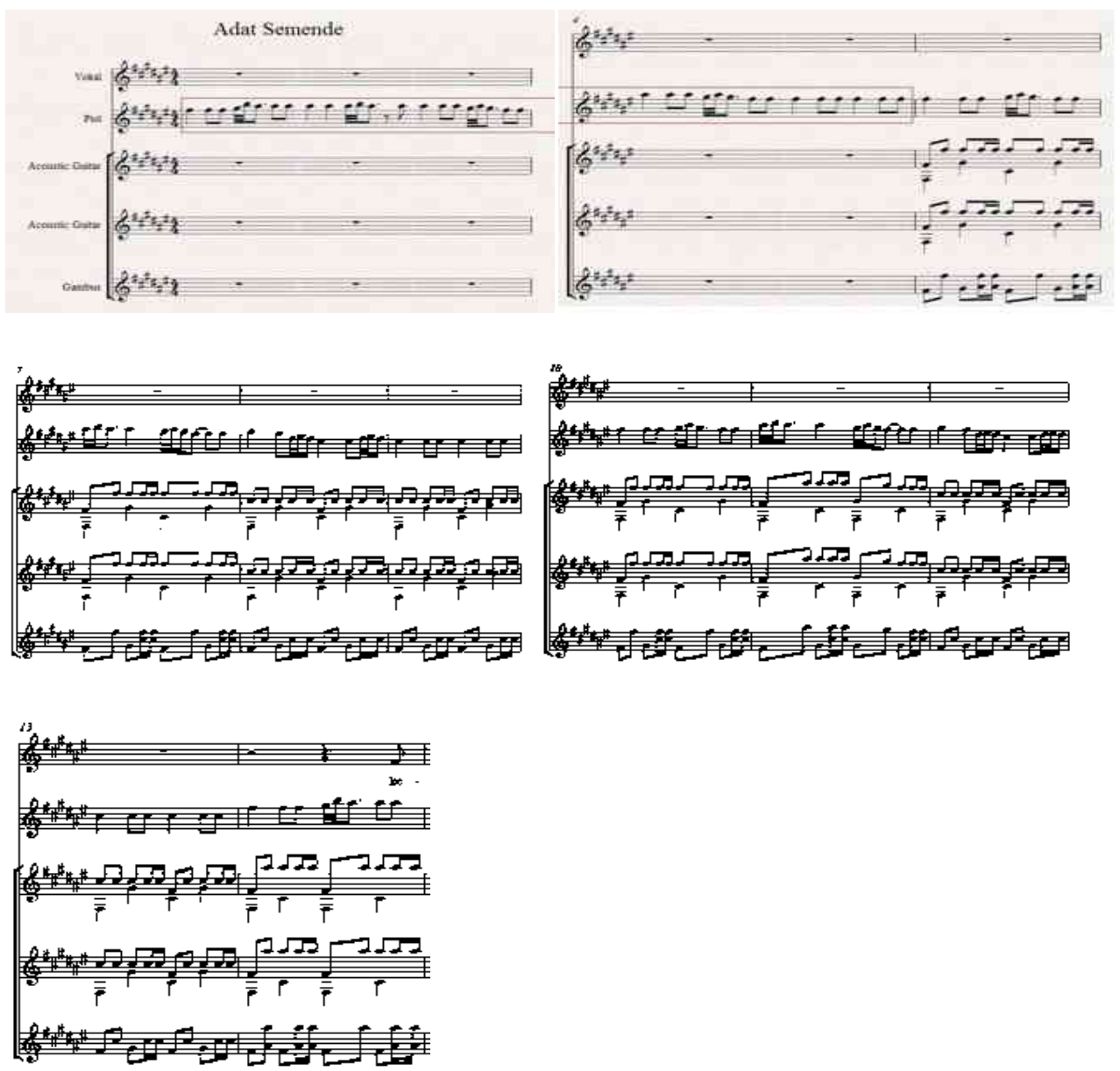

Melodi Frase A

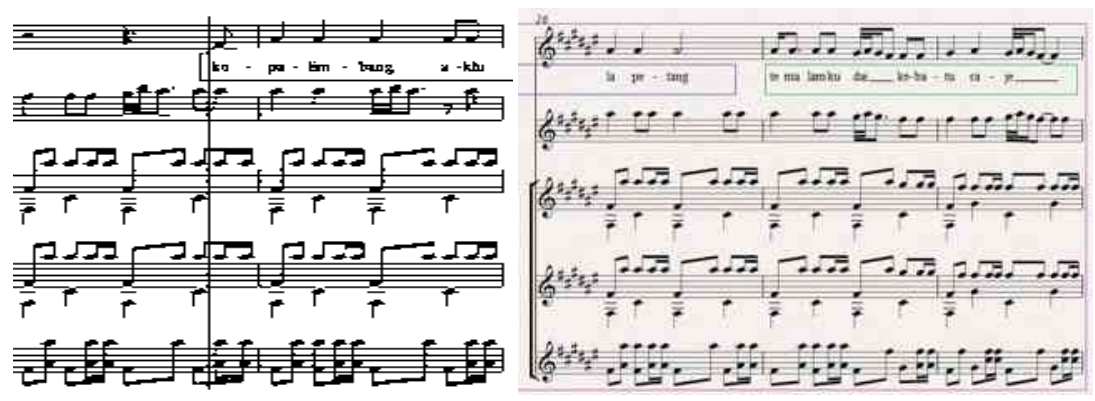

Tanda garis yang berwarna ungu menunjukkan frase A sedangkan garis berwarna biru untuk menunjukan sampiran pantun baris pertama dan garis yang berwarna hijau untuk menunjukkan sampiran pantun pada baris ke dua. 
Notasi jembatan Ngajak dan masuk frase B

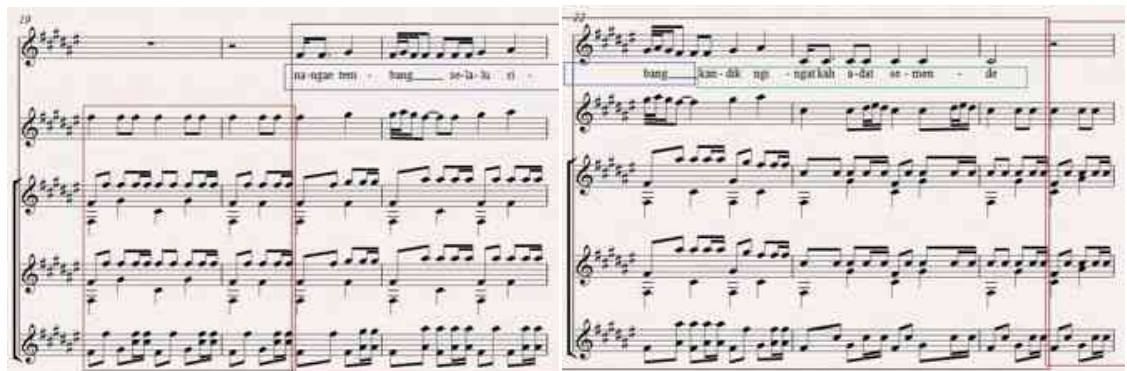

Notasi yang diberikan tanda garis berwarna merah menunjukkan melodi jembatan ngajak, sedangkan garis berwarna coklat menunjukkan frase $B$ dan garis berwarna biru dalam frase $B$, merupakan isi dalam pantun pada baris ke tiga, sedangkan garis warna hijau itu masuk pada isi dalam pantun pada baris keempat, garis berwana merah sudah masuk lagi pada jembatan ngajak.

Notasi repetisi frase B

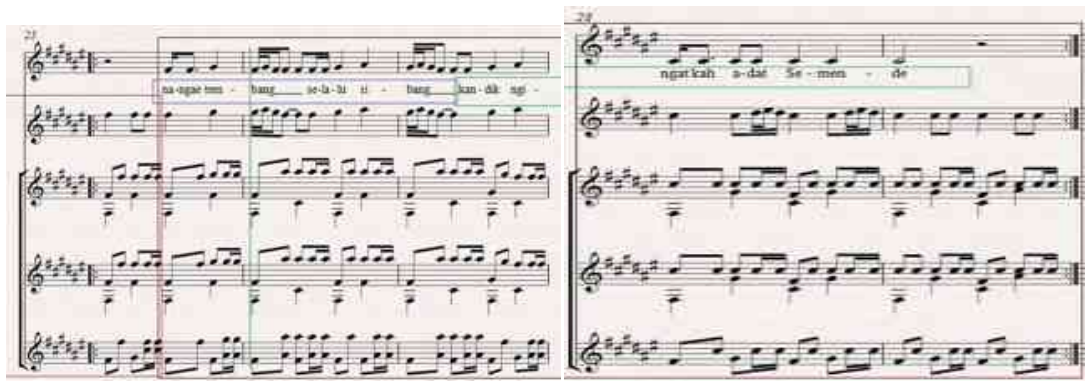

Pada notasi di atas yakni repetisi frase B diberikan tanda pengulang yang berbentuk tanda titik dua. Notasi Nutup
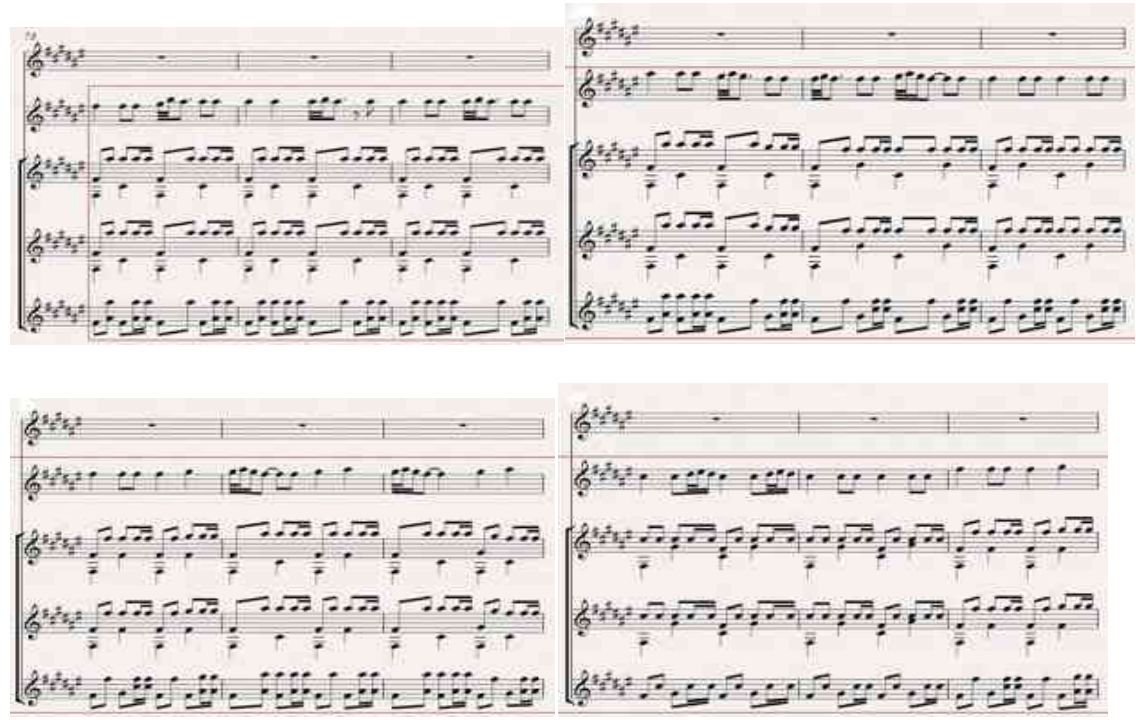


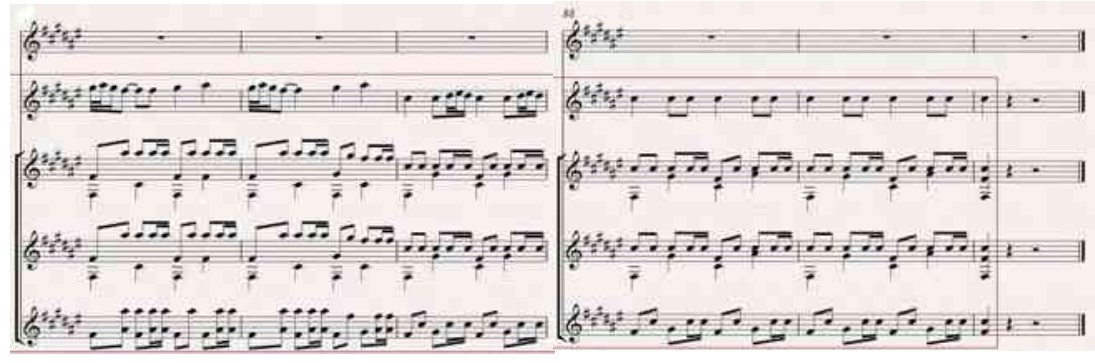

Pembahasan mengenai struktur rejung di atas berlaku bagi seluruh teks pantun terkecuali satu teks pantun yang berjudul "Usul Seminggu". Pada teks ini -Usul Seminggu - struktur yang dimiliki berbeda. Perbedaan tersebut disebabkan oleh susunan struktur pantunnya. Hal ini dapat terlihat pada bagan berikut ini.

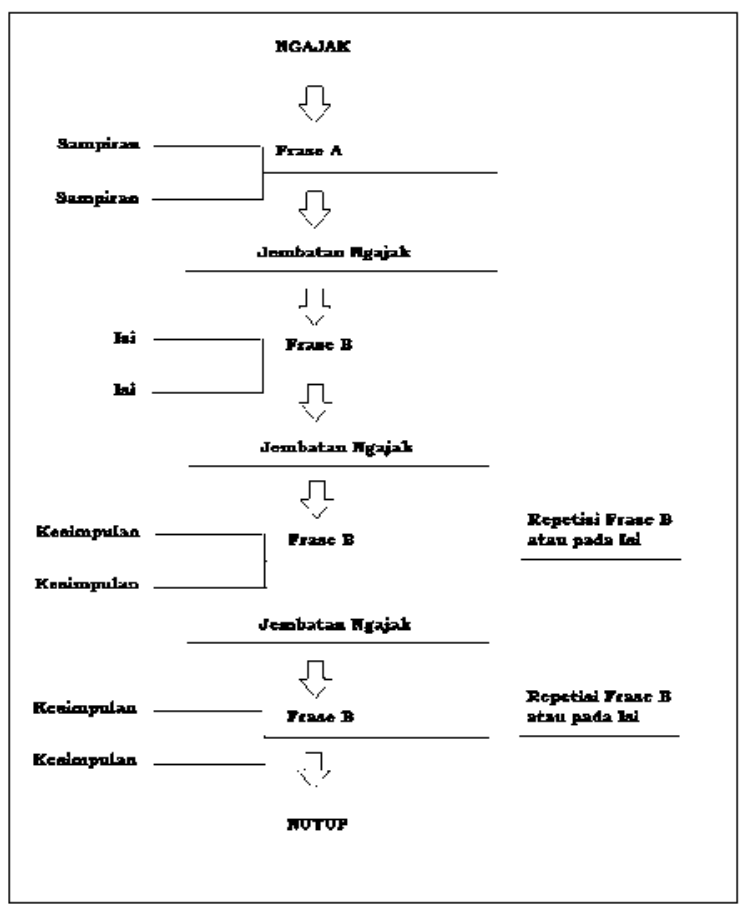

Gambar 3. Struktur Rejung Pada Lagu Berjudul "Usul Seminggu"

Bagan di atas apabila dihadirkan dengan menyertakan pantun serta ditunjukkan identifikasi susunan struktur pantunnya dapat terlihat seperti di bawah ini. 
thad seminkou

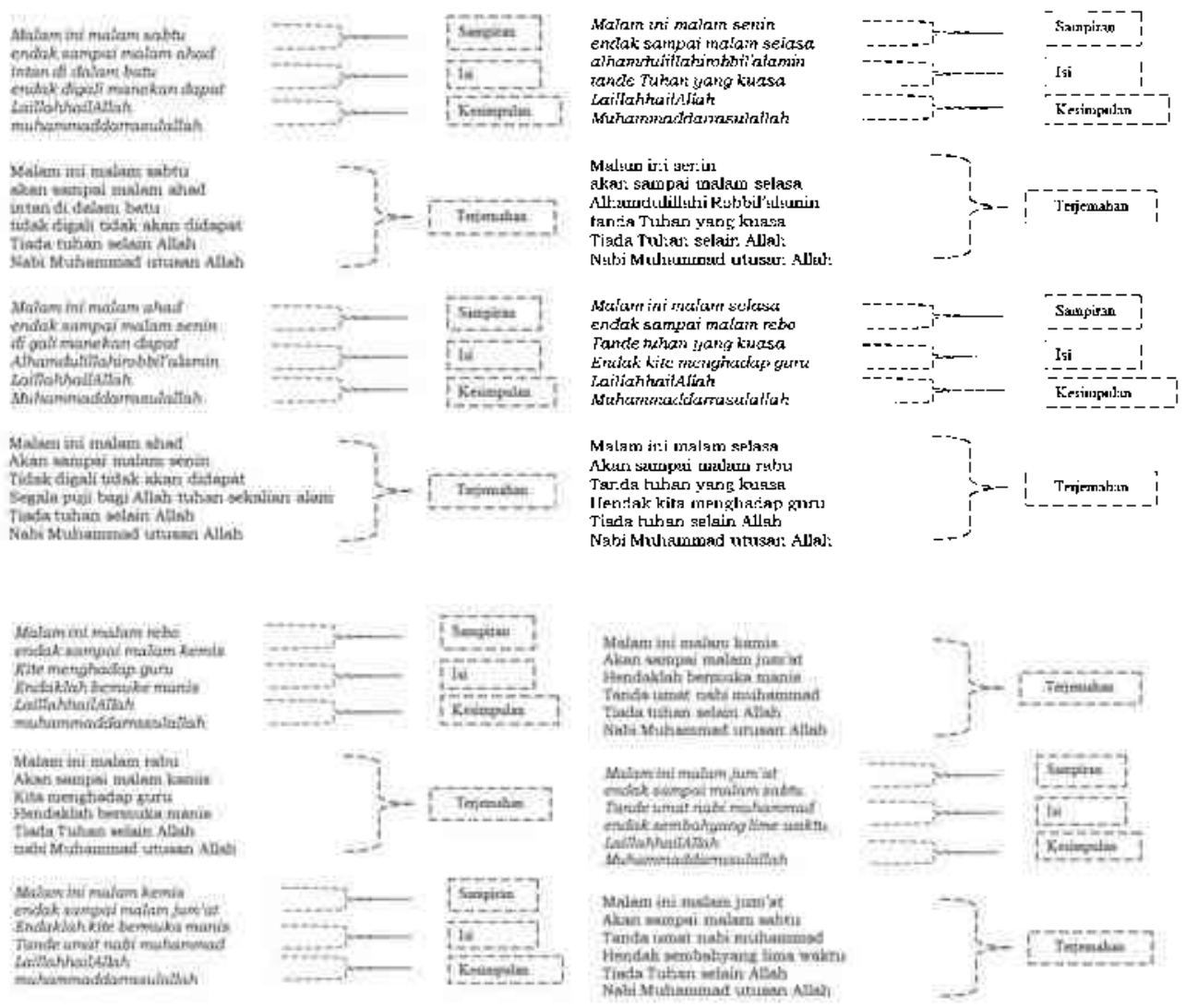

Pada teks pantun di atas dan pada konteks pertunjukan rejung, frase lagu yang direpetisi atau di ulangulang dalam lagu berjudul "Usul Seminggu" tersebut terletak pada kesimpulan dan bukan pada isi dalam pantun. Hal ini yang membedakan dengan lagu rejung yang lain. Secara lebih jelas struktur rejung pada lagu berjudul "Usul Seminggu" dapat terlihat pada notasi di bawah ini.

Notasi Ngajak

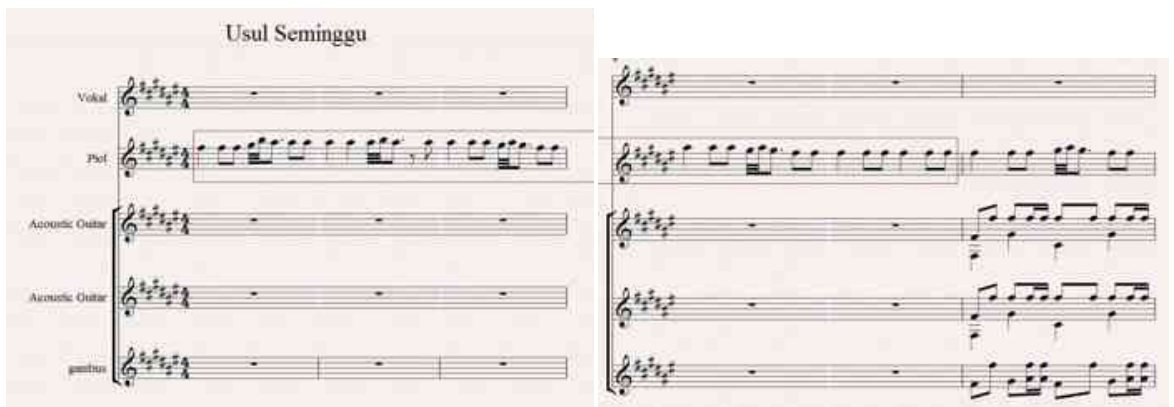




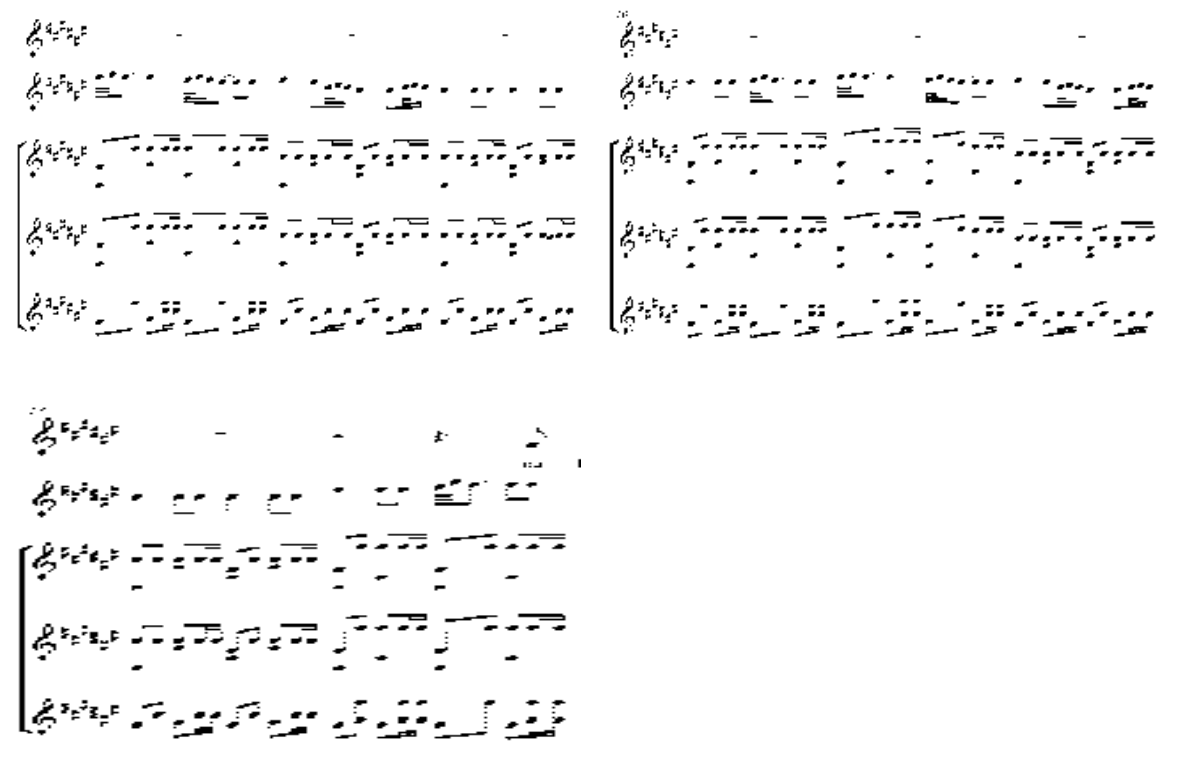

Melodi Frase A

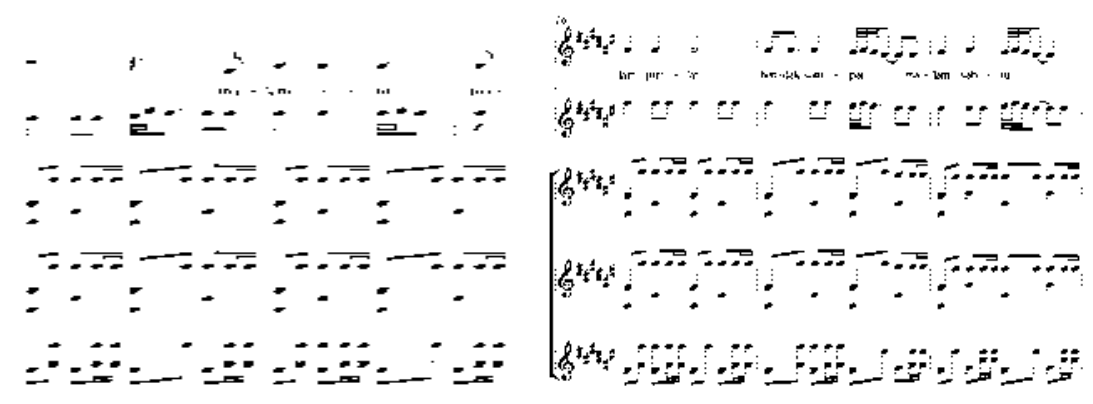

Tanda garis yang berwarna ungu menunjukkan frase A sedangkan garis berwarna biru untuk menunjukan sampiran pantun baris pertama dan garis yang berwarna hijau untuk menunjukkan sampiran pantun pada baris ke dua.

Notasi jembatan Ngajak dan masuk Melodi frase B

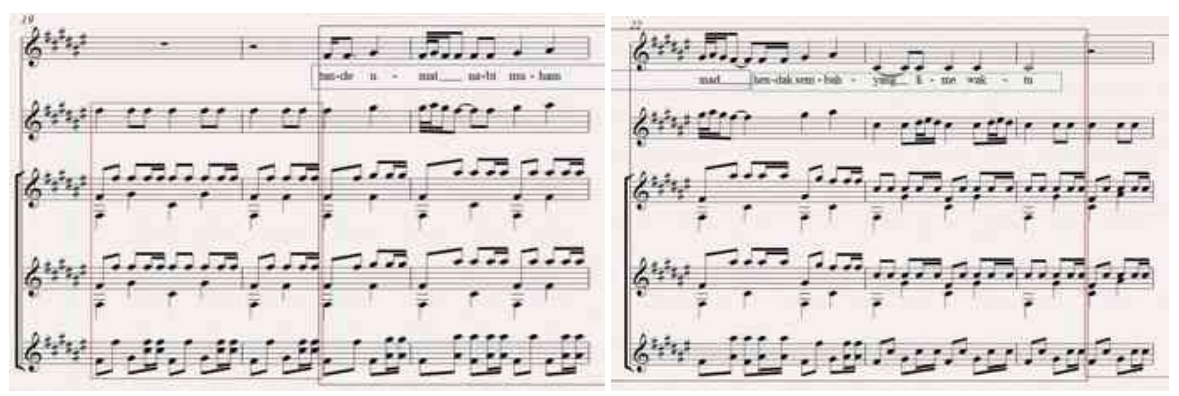

Notasi yang diberikan tanda garis berwarna merah menunjukkan melodi jembatan ngajak, sedangkan garis berwarna coklat menunjukkan frase $B$ dan garis berwarna biru dalam frase $B$, merupakan isi dalam pantun pada baris ke tiga, sedangkan garis warna hijau itu masuk pada isi dalam pantun pada baris keempat, garis berwana merah sudah masuk lagi pada jembatan ngajak. 
Notasi repetisi frase $B$

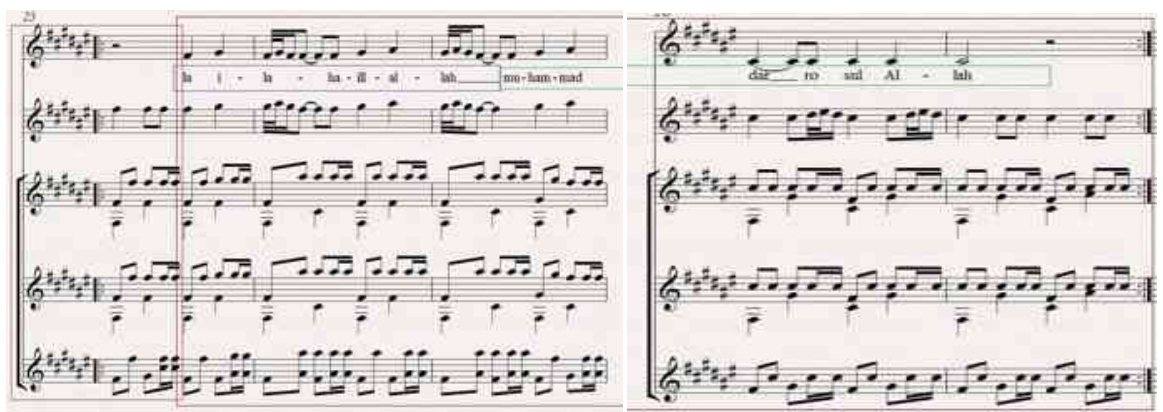

Pada notasi di atas yakni repetisi frase B diberikan tanda pengulang yang berbentuk tanda titik dua. Adapun pada repetisi dalam frase $B$ garis berwarna biru itu menunjukkan kesimpulan pantun, baris ke lima garis berwarna hijau adalah untuk menunjukkan kesimpulan pada pantun beris ke enam.

Notasi Nutup
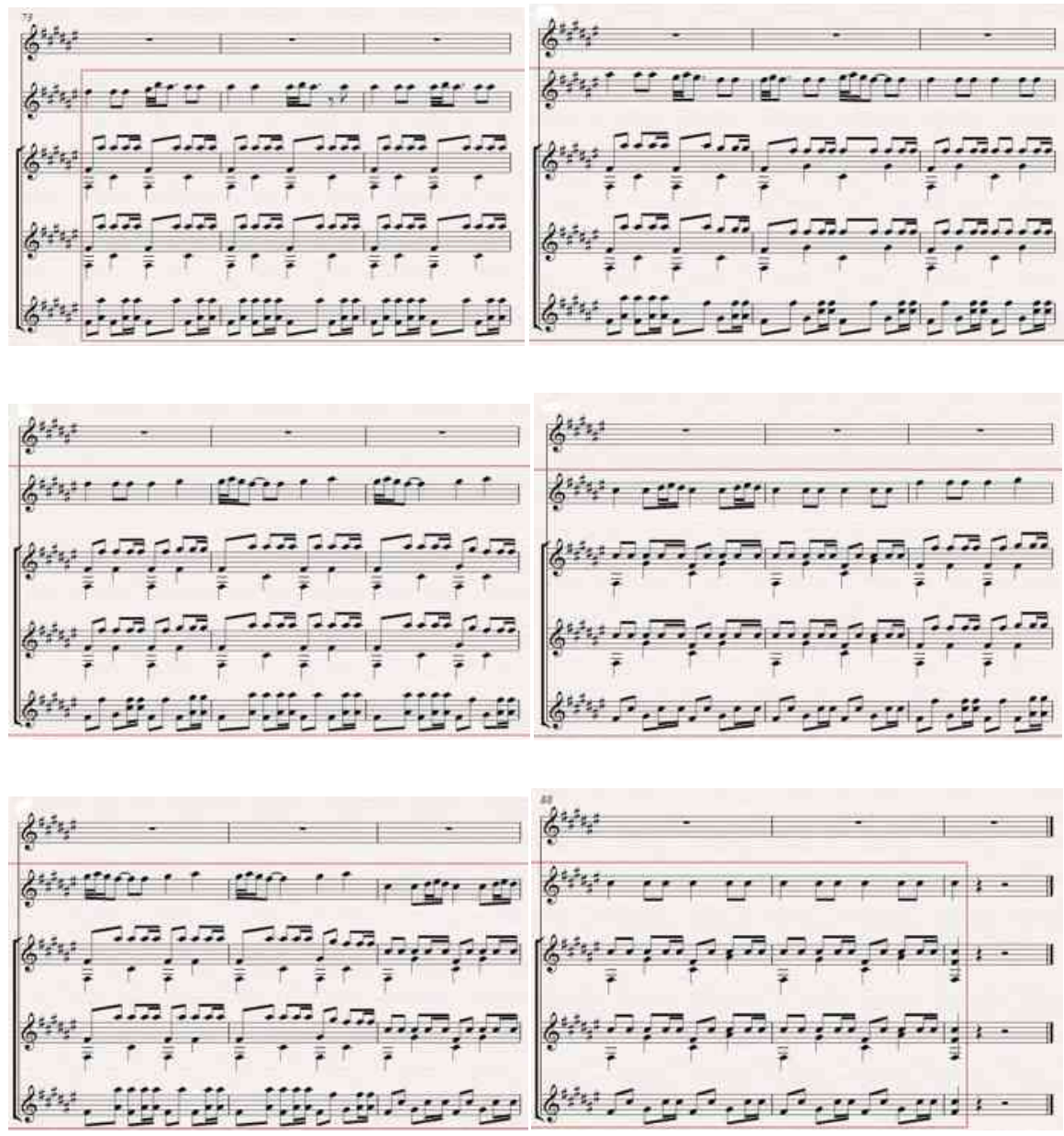

Paparan mengenai struktur rejung baik yang pertama dan yang kedua ini menunjukkan bahwa rejung dalam sajiannya tidak dapat terlepas dari repetisi-repetisi. Repetisi teks pantun ini menjadi satu ciri utama pada pertunjukan rejung. Menurut Rasid, fungsi dari pengulangan ini bertujuan agar penonton dapat dengan mudah 
menghafal dan mengingat pesan moral yang terkandung di dalam pertunjukan rejung. Adapun pernyataan Rasid secara eksplisit dapat terlihat pada petikan wawancara berikut ini: "Ngulang-ngulang lagu di rejung ini sebagai penegas saje, supaye kite cepat hafal isinye". Artinya pengulangan pada permainan rejung sebagai penegas, agar kita cepat hafal isi pantunnya. (wawancara, Rasid 06 Februari 2014).

Paparan mengenai struktur rejung di atas pada akhirnya menunjukkan bahwa repetisi pantun pada rejung baik pada isi maupun kesimpulan bertujuan agar masyarakat adat suku Semende di Kecamatan Pulau Beringin dapat memahami dan dapat dengan mudah menghafal pesan yang disampaikan melalui pertunjukan rejung.

\section{Konsep Gotong Royong Pada Pertunjukan Rejung}

Rejung yang hidup di alam pedesaan dan disajkan dengan melibatkan lebih dari satu pemain menunjukkan bahwa di dalam mengolah imajinasi musikal seniman rejung tidaklah sendiri, melainkan jenis seni ini masuk sebagai kategori seni kolektif. Kategori seni kolektif ini mengandung pengertian bahwa musik sebagai salah satu produk budaya kehadirannya mampu menggerakkan kesadaran masyarakat terhadap kekuatan potensi seni yang dimiliki masyarakat yang bersangkutan.

Kekuatan kolektif yang dimaksud, menurut M. Habib Mustopo adalah menggambarkan kepribadian komunal atau masyarakat setempat. Menurutnya, musik mampu menyatakan semangat atau spirit kebersamaan dari komunitas yang bersangkutan (1983: 58). Semangat kebersamaan ini sangat kontekstual dan relevan dengan pengertian Semende. Menurut Iskandar, Semende berasal dari kata "seme" dan "ende" yang mengandung pengertian sesama atau kebersamaan bergotong royong (2003: 52). Penamaan suku Semende apabila dikorelasikan dengan rejung dapat ditemukan satu benang merah bahwa di dalam rejung terkandung pula semangat kebersamaan yang bukan lain adalah manifestasi dari nama suku mereka sendiri.

Menurut Kordin, semangat kebersamaan ini apabila dituangkan dalam permainan rejung disebut juga dengan permainan kerjasama atau gotong royong. Kordin memberikan keterangkan bahwa gotong royong dalam pertunjukan rejung ini disebut dengan setebak (wawancara 20 Agustus 2014). Istilah lokal tersebut secara faktual hingga kini masih dijumpai dalam sajian pertunjukan rejung. Peneliti menduga, istilah setebak yang memiliki padanan kata dengan gotong royong ini muncul dan digunakan dalam konteks rejung karena masyarakat pendukung rejung merupakan masyarakat yang hidup dan berdomisili di wilayah pedesaan, di mana kehidupannya masih lekat dengan tradisi gotong royong.

Hal ini dijelaskan pula oleh Kartodirjo, secara kultural, gotong royong menurutnya merupakan salah satu bentuk solidaritas khas masyarakat agraris tradisional. Menurutnya masyarakat-masyarakat ini terikat satu sama lain berdasarkan relasi sosial yang disebut ikatan primordial, yaitu lewat ikatan keluarga, dekatnya letak geografis, serta iman kepercayaan (1987: 254). Menurut Kordin, setebak adalah menyenandungkan pantun dengan iringan musik yang dimainkan secara bersama-sama, bergiliran, atau memainkan musik dengan alat musik sambil menyenandungkan pantun-pantun (wawancara, 06 Februari 2014). 
Pada saat pantun dan musik disenandungkan, posisi antara penembang atau orang yang memainkan ayunan vokal dengan orang yang memainkan ayunan alat musik harus memiliki kesamaan sehingga terbentuk apa yang dinamakan dengan kebersamaan. Munculnya istilah kebersamaan dalam permainan rejung cukup relevan ketika dihubungkan dengan arti kata "Semende" yang berarti kebersamaan. Pada konteks ini muncul pemahaman bahwa untuk memunculkan keselarasan dalam bermain, antara pemain rejung satu dan yang lain harus peka agar dapat terjalin keselarasan. Kebersamaan yang hasilnya berupa sajian rejung yang selaras oleh masyarakat adat suku Semende dinamakan dengan istilah seirama. Seirama ini berarti permainan antara ayunan alat musik satu dengan alat musik yang lain tidak sumbang, bahkan dengan penembang tidak boleh menghasilkan ayunan yang tidak selaras.

Bahkan untuk permainan gitar pemain harus memperhatikan nada-nadanya. Artinya untuk dapat menciptakan musik yang seirama pada gitar, antara pemain gitar satu dengan gitar ke dua umumnya nadanya harus sama. Kesamaan permainan nada ketika dibunyikan secara bersama-sama dalam perspektif musik barat dinamakan dengan unisono. Unisono adalah permainan melodi dengan dua alat musik atau lebih dengan nada melodi yang dimainkan memiliki kesamaan. Wujud unisono dalam permainan gitar dan dambus dapat terlihat pada notasi di bawah ini dan diberikan tanda panah putus-putus sebagai tanda yang mengarahkan pada kesamaan nada ayunan.

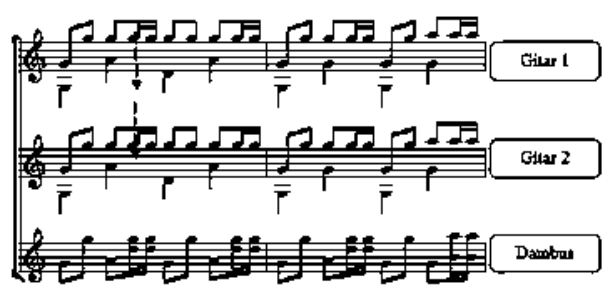

\section{SIMPULAN}

Rejung merupakan seni pertunjukan rakyat, di mana teks lagunya berbentuk pantun yang disenandungkan bersama dengan permainan gitar, piol - berbentuk seperti biola- dan dambus. Penggunaan istilah rejung selaras dengan pengertiannya yakni berarti 'pantun'. Munculnya rejung bermula dari kesenian ta'dut dan sardudun. Ta'dut adalah seni sastra tutur berupa pantun-pantun yang isinya pesan-pesan keagamaan -agama Islam. Sedangkan sardudun adalah seni sastra tutur yang berisi pantun-pantun mengenai hukum adat suku Semende. Keduanya, yakni ta'dut dan sardudun dalam sajiannya tidak menyertakan musik dan hanya menyajikan vokal.

Pantun yang dilantunkan dalam sajian pertunjukan rejung, umumnya diulang dua sampai tiga kali putaran. Repetisi teks pantun menjadi hal utama dalam sajian pertunjukan. Sajiannya bermula dari seorang penembang rejung menembangkan pantun-pantun yang disajikan kurang lebih terdiri dari empat pantun, kemudian diringi oleh pemain musik, setelah penembang rejung menembangkan pantunnya, maka pantun tersebut diulangi lagi untuk ditembangkan oleh penembang yang lainnya satu persatu dengan cara bergiliran. 
Pemain rejung secara umum berjumlah lima orang. Keahlian bermain rejung diperoleh dari pengalaman secara langsung dan tidak ada sistem pembelajaran secara formal. Arena pentas yang digunakan dalam pertunjukan rejung terbagi menjadi tiga tempat. Masing-masing tempat dapat digunakan sesuai dengan situasi yang dihadapi. Adapun ketiga tempat arena pentas tersebut adalah: (1) panggung terbuka; (2) halaman rumah; (3) di dalam rumah. Sedangkan untuk waktu pertunjukan, biasanya tampil dalam dua tema acara yang berbeda. Tema pertama menyangkut dengan kegiatan keagamaan, dan tema kedua menyangkut dengan kegiatan kemasyarakatan atau adat istiadat.

Secara musikal, terbentuknya melodi-melodi vokal awal dikonstruksikan oleh melodi yang dibangun oleh alat musik piol dan ini dalam rejung dikenal dengan istilah ngajak. Ngajak ialah permainan melodi awal sekaligus berfungsi sebagai tanda masuknya vokal agar tidak sumbang dalam permainan rejung.

Akhir laporan penelitian ini disarankan, bahwa ungkapan nilai-nilai yang dikemas dalam pertunjukan rejung sungguh sangat perlu memperoleh wadah dan sarana sehingga keberadaannya dapat abadi dan terus menerus dipelajari, dipahami, dan dikembangkan dari generasi ke generasi. Semoga.

\section{DAFTAR PUSTAKA}

Arikunto, S. Prosedur Penelitian Suatu Pendekatan Praktek, (Jakarta: Rineka Cipta, 1998)

Blacking, John. 1976. How Musical is Man. (London: Faber and Faber. 1976)

Hanafiah Djohan dan Tim, Direktori Kesenian Sumatera Selatan. (Palembang: Dinas Kebudayaan dan Pariwisata Propinsi Sumatera Selatan, 2006)

Iskandar, "Kedudukan Anak Tunggu Tubang dalam Pewarisan Masyarakat Adat Suku Semende di Kota Palembang" (Tesis Program Studi Magister Kenotariatan Universitas Diponegoro, 2003)

Kartodirjo, Sartono. "Gotong Royong: Saling Menolong dalam Pembangunan Masyarakat Indonesia", dalam Nat J Colletta dan Umar Kayam, Edt. Kebudayaan dan Pembangunan, Sebuah Pendekatan Terhadap Antropologi Terapan di Indonesia. (Jakarta: Yayasan Obor Indonesia, 1987, 254 - 271).

L.E. Sumaryo, Komponis, Pemain Musik dan Publik, Sebuah Brosur untuk Remaja. (Jakarta: Pustaka Jaya, 1978)

Miller, Hugh. M, Apresiasi Musik. (Yogyakarta: Yayasan Lentera Budaya, 2001)

Mustopo, M. Habib, Manusia Dan Budaya Kumpulan Essay IImu Budaya Dasar. (Surabaya: Usaha Nasional, 1983)

Siswanto Silo, "Pesan Moral pada Pertunjukan Rejung di Kecamatan Pulau Beringin Sumatera Selatan" (Tesis Program Studi Magister Penciptaan dan Pengkajian Seni Institut Seni Indonesia Surakarta, 2015)

Thaddeus Jones, George, Music Theory. (New York : Barnes dan Noble Book, 19. 